\title{
Influence of Dosage of Super Plasticizer on the Mechanical Properties of Binary Blended Concrete
}

\author{
A.Mallinadh Kashyap, E.T.Chakrapani, L.Narasimha Murthy, S.Suryanarayana Raju
}

\begin{abstract}
Women are an equal soul of men by comprises men in her name itself but really they are treated equal among men. There is a broad gap in between past and present centuries. Women are treated poorly on past centuries by getting huge works, asking more dowries and even killing female infant but in present century these has been reduced and crimes are increased more in numbers against women like abducted, murdered, raped and harassed in various ways. This assessment is on women's tracking system which helps them in their safety and security. Although there are $n$ numbers of tracking devices still crimes against women are in an increasing rate. These crimes have to be reduced in an effective ways of implementing versatile tracking system by combining various technologies into a single integrated unit.
\end{abstract}

Keywords-Audio and Image, GPS, GPRS, GSM, Sensors.

\subsection{INTRODUCTION}

Mineral and chemical admixtures play a vital role in the strength enhancement of concrete. The chemical admixtures have the ability to increase the workability of the concrete considerably and also imparts strength enhancement of the concretes considerably. In India, the chemical admixtures are generally used in the construction of high rise structures, long span bridges and in ready mix concretes and at present, various chemical and mineral admixtures are available in the market as per the needs of the users,

The advantages will be found when chemical admixtures produce high workable concretes imparting in strength by keeping the objective for placing. It also produces concrete with low water requirements and workable concrete with less cement content. Use of chemical admixture is increasing now a days because of its possessing advantages for both fresh and hardened stages of concrete. The use of chemical admixtures in concretes have positive effects on the fresh and hardened properties of the concrete. In the fresh stage, use of chemical admixture will generally reduces the bleeding effects due to the decrease in water content. Also, the use of mineral admixtures in concrete increases the mechanical properties of the concrete as well as the durability of the concrete.

With the increase in the dosage of chemical admixture, the concrete leads to gain good ability in addition to slump. Further, over dosage of chemical admixture found to deteriorate the properties of concrete with reporting of lower

Revised Manuscript Received on July 10, 2019.

A.Mallinadh Kashyap, Assistant Professor, Department of Civil Engineering, GIET Engineering College, Rajahmahendravaram, A.P, India.

E.T.Chakrapani, Assistant Professor, Department of Civil

Engineering, GIET Engineering College, Rajahmahendravaram, A.P, India.

L.Narasimha Murthy, Professor, Department of Chemistry, GIET

Engineering College, Rajahmahendravaram, A.P, India.

S.Suryanarayana Raju, Professor \& Principal, Department of

Chemistry, GIET Engineering College, Rajahmahendravaram, A.P, India. compressive strengths [1].Modified poly carboxylic ether found more effective than chemical admixtures. At better degree of workability and mechanical properties. If the low dosages of chemical admixtures are used than optimal dosage, increase in mineral admixture dosage will help in enhancing the characteristics of concrete [2]. The compressive strength of concrete subjected to high ambient temperatures is significantly influenced by the curing period in wet condition and also the addition of chemical admixture [3]. Over dosages of chemical admixtures were found to decrease the properties of concrete resulting in lower compressive strengths and higher porosity [4].Optimum percentage of $7.5 \%$ mineral admixture silica fume and metakaoline gives better results in terms of hardened properties of cement concrete [5,6].

The present results showed in this study gave a far better results than when compared with the ordinary controlled concrete on par with the mechanical properties of the controlled concrete. In this study, it was aimed to develop a sustainable concrete by utilizing the mineral and chemical admixtures as a replacement to conventional cement concrete so as to increase the mechanical properties of the concrete.

\subsection{EXPERIMENTAL DETAILS}

Mix design considered in the present study is M 35 grade concrete as per IS 10262:2009 code with normal constituents of concrete like locally available UltraTech OPC 53 grade cement. River sand and mechanically crushed $20 \mathrm{~mm}$ conventional granite. The experimental investigation was divided into two phases. In the first phase of investigation, it was aimed to develop and identify the optimum dosage of mineral admixtures viz., fly ash and GGBS. In the second phase of investigation, the obtained optimal mix was tested for various dosages of chemical admixture viz., HI-FORZA 245. The workability test results for various replacement levels of mineral admixtures are presented in Table1 and the corresponding details are pictorially depicted in Fig1. Further, The mechanical properties in the similar lines were presented in Table 2 and Fig.2. The optimal mix obtained in this study is shown via Table 3 with various replacement levels of chemical admixtures. Pictorial representations of the same are shown in Fig. 3 and Fig.4.

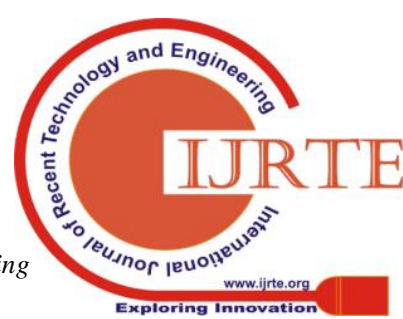


INFLUENCE OF DOSAGE OF SUPER PLASTICIZER ON THE MECHANICAL PROPERTIES OF BINARY BLENDED CONCRETE

2.0 RESULTS AND DISCUSSION

2.1WORKABILITY TESTS FOR FRESH CONCRETE

Table 1 : Workability tests for various replacements levels of mineral admixtures to cement

\begin{tabular}{|c|c|c|c|c|c|c|}
\hline S.No & Mix Description & Mix Designation & $\begin{array}{c}\% \text { of mineral } \\
\text { admixtures }\end{array}$ & $\begin{array}{c}\text { Slump Cone Test } \\
(\mathrm{mm})\end{array}$ & $\begin{array}{c}\text { Compaction } \\
\text { factor }\end{array}$ & $\begin{array}{c}\text { Vee-bee test } \\
(\mathrm{sec})\end{array}$ \\
\hline 1. & M35 CM & M1 & 0 & 60 & 0.84 & 5 \\
\hline 2. & $\begin{array}{c}(5 \%+5 \%) \\
\text { FA+GGBS }\end{array}$ & M2 & 10 & 60 & 0.86 & 6 \\
\hline 3. & $\begin{array}{c}(5 \%+10 \%) \\
\text { FA+GGBS }\end{array}$ & M3 & 15 & 50 & 0.88 & 8 \\
\hline 4. & $\begin{array}{c}(10 \%+5 \%) \\
\text { FA+GGBS }\end{array}$ & M4 & 15 & 55 & 0.86 & 8 \\
\hline 5. & $\begin{array}{c}(7.5 \%+7.5 \%) \\
\text { FA+GGBS }\end{array}$ & M5 & 15 & 58 & 0.85 & 7 \\
\hline 6. & $\begin{array}{c}(10 \%+10 \%) \\
\text { FA+GGBS }\end{array}$ & M6 & 20 & 50 & 0.89 & 8 \\
\hline
\end{tabular}
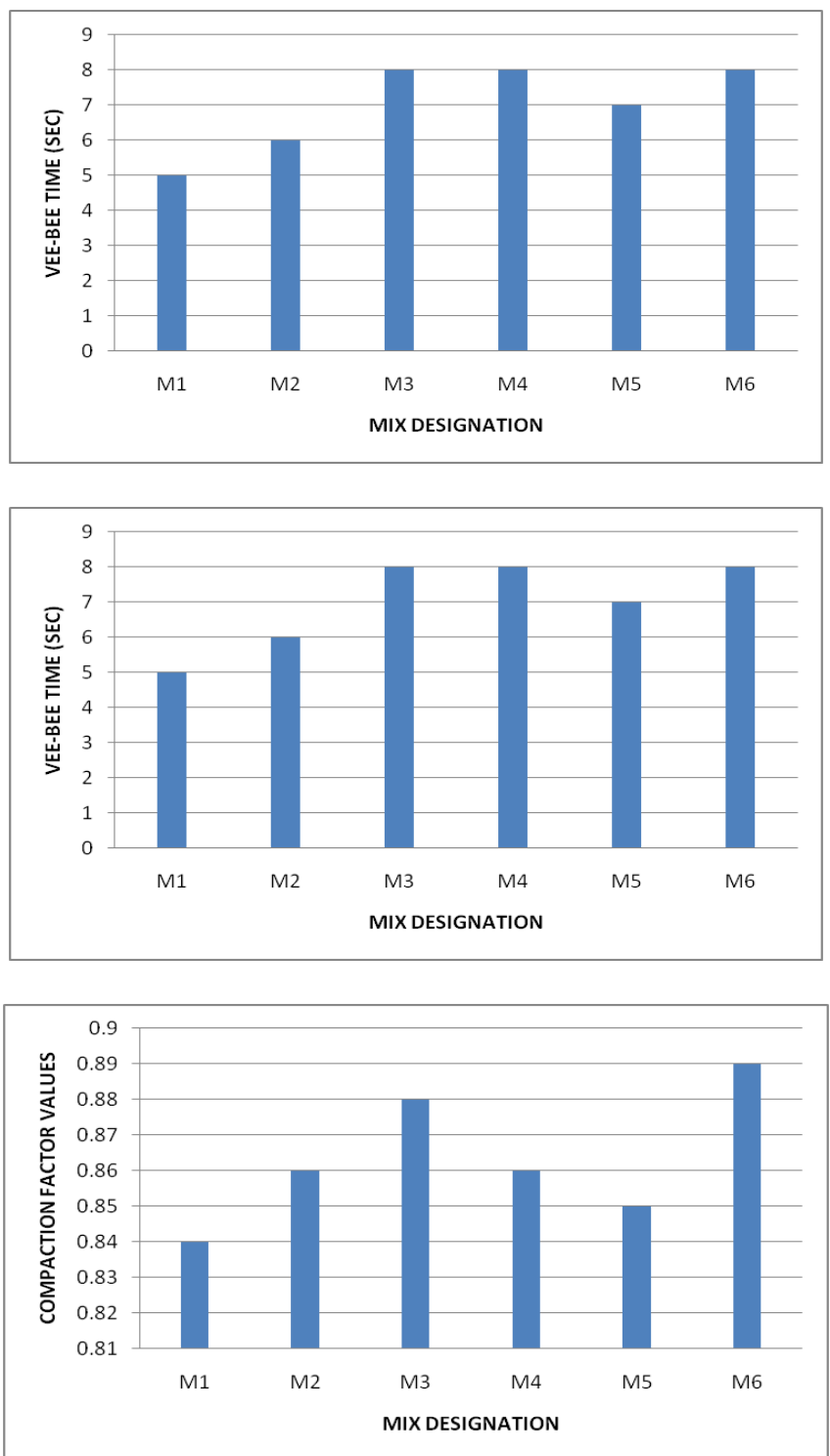

Fig. 1 Workability test results for slump cone, compaction factor and vee-bee time for mineral admixture replacement to cement

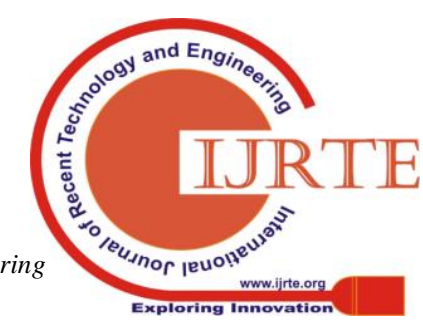


From Table.1, Fig.1,it is observed that as the percentage replacement levels of blended mineral admixture increases, the fresh properties of concrete decreases and for mix M5, it was found to be effective of all the mixes and it was considered for the further study.

Table 2: Test results of M35 grade concrete with various replacements of mineral admixtures to cement

\begin{tabular}{|c|c|c|c|c|c|c|}
\hline S.No & $\begin{array}{c}\text { Mix } \\
\text { Descriptio } \\
\mathrm{n}\end{array}$ & $\begin{array}{l}\text { Mix } \\
\text { Design } \\
\text { ation }\end{array}$ & $\begin{array}{c}\% \text { of } \\
\text { mineral } \\
\text { admixtu } \\
\text { res }\end{array}$ & $\begin{array}{c}\text { Compress } \\
\text { ive } \\
\text { Strength } \\
\text { (MPa) }\end{array}$ & $\begin{array}{c}\text { Split- } \\
\text { tensile } \\
\text { strength } \\
(\mathrm{MPa})\end{array}$ & \begin{tabular}{|c} 
Flex \\
ural \\
Stren \\
gth \\
(MP \\
a)
\end{tabular} \\
\hline 1. & M35 CM & M7 & 0 & 43.33 & 3.82 & 5.20 \\
\hline 2. & $\begin{array}{c}(5 \%+5 \%) \\
\text { FA+GGB } \\
\mathrm{S}\end{array}$ & M8 & 10 & 44.00 & 3.86 & 5.25 \\
\hline 3. & $\begin{array}{c}(5 \%+10 \%) \\
\text { FA+GGB } \\
S \\
\end{array}$ & M9 & 15 & 44.44 & 3.89 & 5.30 \\
\hline 4. & $\begin{array}{c}(10 \%+5 \%) \\
\text { FA+GGB } \\
\text { S }\end{array}$ & M10 & 15 & 43.11 & 3.80 & 5.18 \\
\hline 5. & $\begin{array}{c}(7.5 \%+7.5 \\
\%) \\
\text { FA+GGB } \\
\text { S }\end{array}$ & M11 & 15 & 45.33 & 3.91 & 5.49 \\
\hline 6. & $\begin{array}{c}(10 \%+10 \\
\%) \\
\text { FA+GGB } \\
\mathrm{S}\end{array}$ & M12 & 20 & 44.00 & 3.78 & 5.20 \\
\hline
\end{tabular}
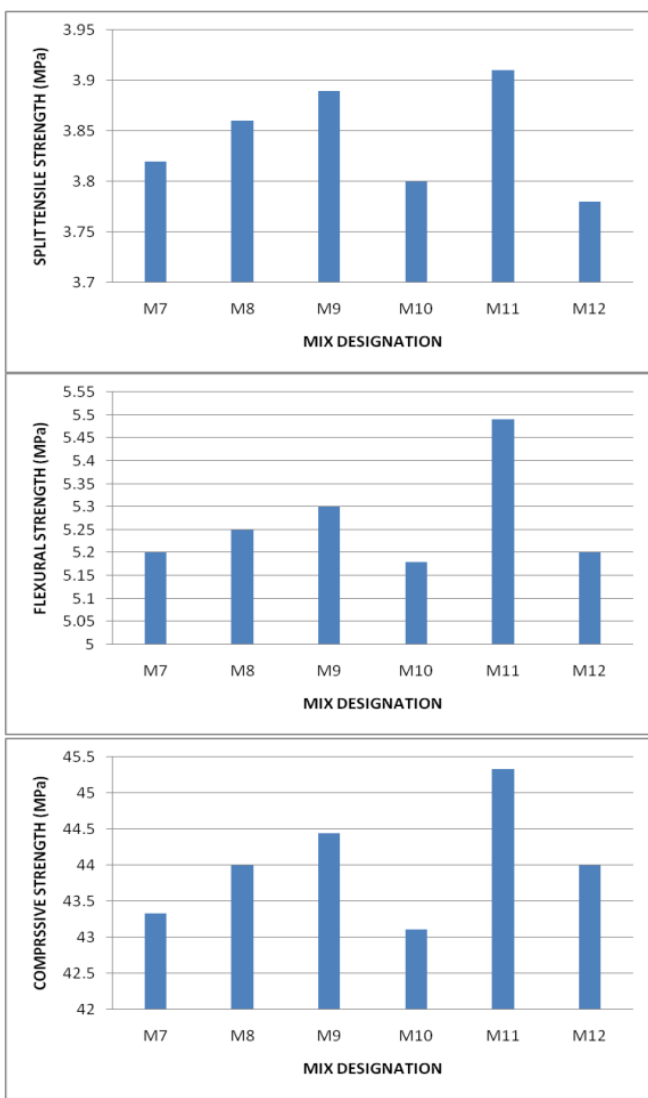

Fig. 2 Mechanical properties of M35 grade concrete with mineral admixture replacement to cement
From Table. 2 , Fig.2,it is revealed that as the percentage replacement levels of blended mineral admixture increases, the hardened properties of concrete increases and for mix M11, it was found to be effective of all the mixes.

Table 3: Test results of M35 grade concrete with various replacements of chemical admixtures

\begin{tabular}{|c|c|c|c|c|c|c|}
\hline S.No & $\begin{array}{c}\text { Mix } \\
\text { Descriptio } \\
n\end{array}$ & $\begin{array}{c}\text { Mix } \\
\text { Designati } \\
\text { on }\end{array}$ & $\begin{array}{c}\% \text { of } \\
\text { chemical } \\
\text { admixtur } \\
\text { es }\end{array}$ & $\begin{array}{c}\text { Slum } \\
\mathrm{p} \\
\text { Cone } \\
\text { Test } \\
(\mathrm{mm})\end{array}$ & $\begin{array}{l}\text { Compa } \\
\text { ction } \\
\text { factor }\end{array}$ & $\begin{array}{l}\text { Vee- } \\
\text { bee } \\
\text { test } \\
\text { (sec) }\end{array}$ \\
\hline 1. & M35 CM & M13 & 0 & 60 & 0.84 & 5 \\
\hline 2. & $\begin{array}{c}(7.5 \%+7.5 \\
\%) \\
\text { FA+GGB } \\
\text { S }\end{array}$ & M14 & 0.5 & 58 & 0.82 & 4 \\
\hline 3. & $\begin{array}{c}(7.5 \%+7.5 \\
\%) \\
\text { FA+GGB } \\
\text { S }\end{array}$ & M15 & 1 & 65 & 0.85 & 4 \\
\hline 4. & $\left(\begin{array}{c}(7.5 \%+7.5 \\
\%) \\
\text { FA+GGB } \\
\text { S }\end{array}\right.$ & M16 & 1.5 & 75 & 0.80 & 2 \\
\hline 5. & $\begin{array}{c}(7.5 \%+7.5 \\
\%) \\
\text { FA+GGB } \\
\mathrm{S}\end{array}$ & M17 & 2 & 85 & 0.83 & 2 \\
\hline
\end{tabular}
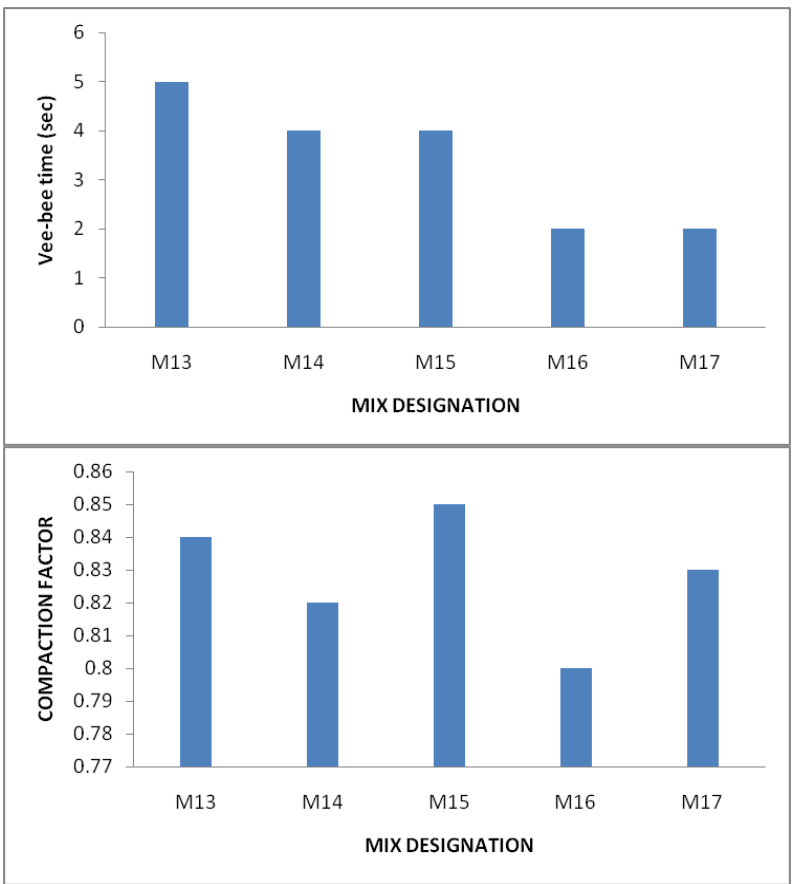

Published By: 


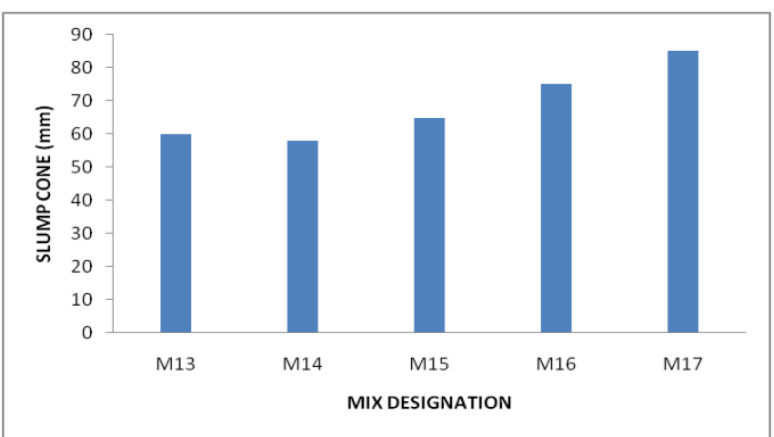

Fig. 3 Workability test results for slump cone, compaction factor and vee-bee time for mineral and chemical admixture replacement to cement

From Table.3 , Fig.3, it is evident that as the percentage replacement levels of chemical admixture increases, the fresh properties of concrete increases for $15 \%$ replacement of SP and for mix M16, it was found to be effective of all the mixes and it was considered for the further study.

Table 4: Mechanical properties of M35 grade concrete with various replacements of chemical admixtures

\begin{tabular}{|c|c|c|c|c|c|c|}
\hline $\begin{array}{c}\text { S.N } \\
\text { o }\end{array}$ & $\begin{array}{c}\text { Mix } \\
\text { Descriptio } \\
n\end{array}$ & $\begin{array}{c}\text { Mix } \\
\text { Designati } \\
\text { on }\end{array}$ & $\begin{array}{c}\% \text { of } \\
\text { chemica } \\
1 \\
\text { admixtu } \\
\text { res }\end{array}$ & $\begin{array}{c}\text { Compress } \\
\text { ive } \\
\text { Strength } \\
\text { (MPa) }\end{array}$ & $\begin{array}{c}\text { Split- } \\
\text { tensil } \\
\mathrm{e} \\
\text { streng } \\
\text { th } \\
(\mathrm{MPa})\end{array}$ & $\begin{array}{c}\text { Flexur } \\
\text { al } \\
\text { Streng } \\
\text { th } \\
(\mathrm{MPa})\end{array}$ \\
\hline 1. & M35 CM & M13 & 0 & 43.33 & 3.82 & 5.20 \\
\hline 2. & $\begin{array}{c}(7.5 \%+7.5 \\
\%) \\
\text { FA+GGB } \\
\text { S }\end{array}$ & M14 & 0.5 & 45.77 & 3.91 & 5.45 \\
\hline 3. & $\begin{array}{c}(7.5 \%+7.5 \\
\%) \\
\text { FA+GGB } \\
\text { S }\end{array}$ & M15 & 1 & 46.00 & 3.92 & 5.48 \\
\hline 4. & $\begin{array}{c}(7.5 \%+7.5 \\
\%) \\
\text { FA+GGB } \\
\text { S }\end{array}$ & M16 & 1.5 & 46.22 & 3.98 & 5.51 \\
\hline 5. & $\begin{array}{c}(7.5 \%+7.5 \\
\%) \\
\text { FA+GGB } \\
\text { S }\end{array}$ & M17 & 2 & 45.77 & 3.86 & 5.19 \\
\hline
\end{tabular}

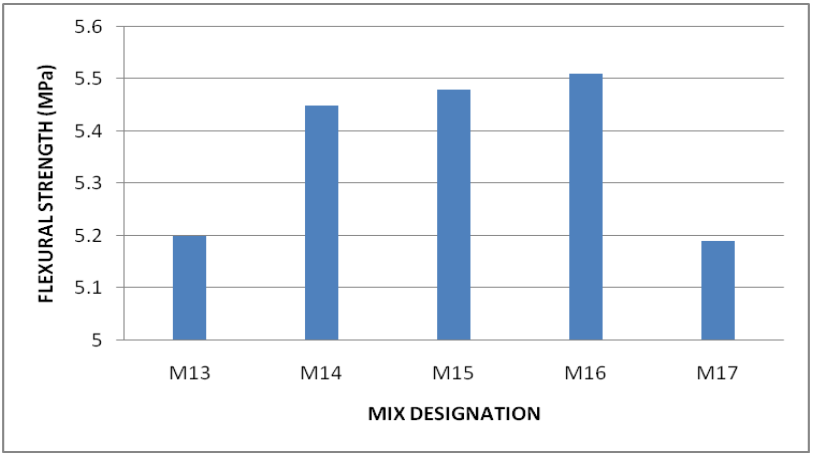

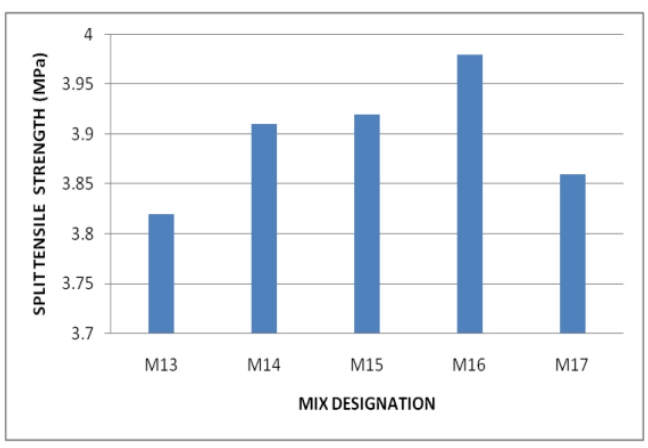

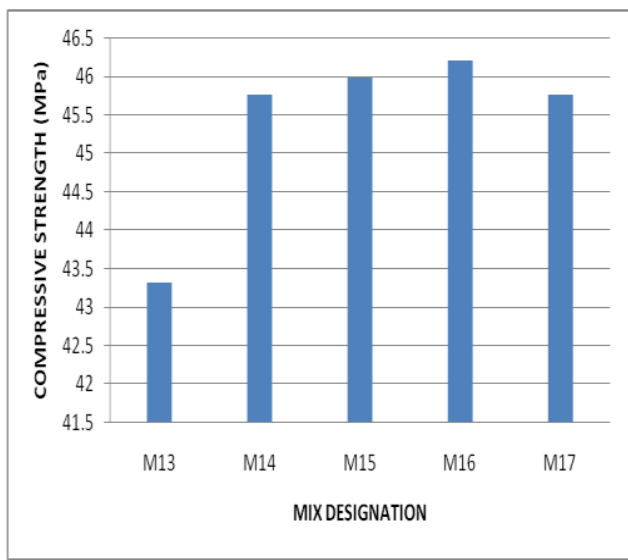

Fig. 4 Mechanical properties of M35 grade concrete with mineral admixture replacement to cement and use of chemical admixture

From Table4 and Fig4, it can be concluded that as the percentage replacement levels of blended mineral and chemical admixture increases, the hardened properties of concrete increases and for mix M16, it was found to be effective of all the mixes.

Workability in all aspects regarding the mineral and chemical admixtures, the ratios of slump cone decreased , compaction factor increased and also the vee-bee time increases and also increased in the case of both mineral and chemical admixtures.

\subsection{CONCLUSIONS}

With the increase in the percentage replacement of mineral admixture to cement, the fresh properties were found to be decreased and showed lower levels of workability. The optimum replacement level of mineral admixture was found to be at $(7.5 \% \mathrm{FA}+7.5 \% \mathrm{GGBS})$ and was reported a high compressive strength value of 45.33 $\mathrm{MPa}$ and the percentage increase in compressive strength was found to be $4.62 \%$. The optimum replacement level of chemcal admixture was found to be at (7.5\%FA+7.5\%GGBS) $1.5 \%$ super plasticizer and was reported a high compressive strength value of $46.22 \mathrm{MPa}$ and the percentage increase in compressive strength was found to be $6.66 \%$. With the use of chemical admixture, the fresh properties as well as the hardened properties were increased for $(7.5 \% \mathrm{FA}+7.5 \% \mathrm{GGBS}) \mathrm{M} 35$ grade concrete. Workability in all aspects regarding the mineral

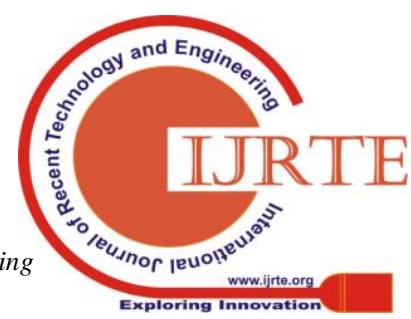


and chemical admixtures, the ratios of slump cone decreased , compaction factor increased and also the veebee time increases and also increased in the case of mineral admixtures \& chemical admixtures.

\section{REFERENCES}

1. 1. Salahaldein Alsadey ," Effect of Superplasticizer on Fresh and Hardened Properties of Concrete", Journal of Agricultural Science and Engineering Vol. 1, No. 2, 2015, pp. 70-74.

2. 2. Luma abdul Ghani,Salwa Rahman Rasheed, "Effect of type and composition of chemical admixture on properties of concrete, International Journal of Civil Engineering and Technology, PP:290-297, 2016.

3. 3.Noor Ahmed Memon, Fahadul Abra, "Effect of the curing conditions and super plasticizer on compressive strength of concrete", International Journal of Engineering Research, Vol.1,No.2,PP:30-36,2016.

4. 4. Muhsen Salam Mohammad, "Influence of super plasticizer compatability on the setting time, strength and stiffening characterstics of concrete".

5. 5. P.Muthupriya, K.Subramanian, B.G.Vishnuram, "Experimental Investigation on High Performance Reinforced Concrete Column with Silica Fume and Fly Ash as admixtures". Asian Journal of Civil Engineering, Vol.12 , No.5 (2011), Pages 597-618.

6. 6.B.B.Patil, P.D. Kumbhar "Strength and Durability Properties of high Performance Concrete incorporating High Reactivity Metakaolin", International Journal of Modern Engineering Research, Vol.2, issue.3,May-June 2012,pages 1099-1104.

7. 7.Dr.Salahldein Alsadey "Influence of Superplasticizer on Strength of Concrete", International Journal of Research in Engineering and Technology, Vol.1, No.3, 2012.

8. 8.S.S.VivekG.Dhinakaran,"Fresh and hardened properties of binary blend high strength self compacting concrete", Engineering Science and Technology, an International Journal,Volume 20, Issue 3, June 2017, Pages 1173-1179.

9. 9. Oveys Afzali-Naniz,Moosa Mazloom, "Assessment of the influence of micro- and nano-silica on the behavior of self-compacting lightweight concrete using full factorial design", Asian Journal of Civil Engineering,January 2019, Volume 20, Issue 1, pp 57-70.

10. 10. Afzali-Naniz, O., \& Mazloom, M. (2018). Effects of colloidal nano-silica on fresh and hardened properties of self-compacting lightweight concrete. Journal of Building Engineering, 20, 400-410.

11. 11. Bernal, J., Reyes, E., Massana, J., León, N., \& Sánchez, E. (2018). Fresh and mechanical behavior of a self-compacting concrete with additions of nano-silica, silica fume and ternary mixtures. Construction and Building Materials, 160, 196-210.

Author for Correspondence : Dr. S Suryanarayana Raju, Principal, GIET Engineering College,

Rajamahendravaram, A P., India, Mobile: 9177122334,

E - Mail: naran.ssnraju@ gmail.com 